\title{
"I make films to be seen": the narrative issue of Flora Gomes
}

\author{
Jusciele Oliveira \\ CIAC \\ Universidade do Algarve, Portugal \\ jusciele@gmail.com
}

\section{ABSTRACT}

The feature films by Flora Gomes: Mortu nega (1988), Udju azul di Yonta (1992), Po di sangui (1996), Nha fala (2002) and Republica di mininus (2012) narrate stories that speak of transits, music, woman, children, war, (neo)colonialism, cosmogony, life, death, love, birth, migration, tradition, modernity, collectivity; taking place in the countryside, or outdoors generally, in an ironic, critical and metaphorical tone of speech. In this sense, the present abstract "I make films to be seen": an analysis of the film narrative of Flora Gomes" proposes to shed light on the elements of narrative cinematography of the fiction films of Flora Gomes which are present in the speech, themes, soundtrack, orality, time, duration, space, camera movements, actors' preparation, the work of illumination of the black body, the scenery, and the visual metaphors of this director. Note that the present text is an extract of some of Gomes's trademarks from doctoral thesis defended in 2018.

\section{KEYWORDS}

African cinemas; narrative cinematography; Flora Gomes.

\section{1 | INTRODUCTION}

The films of Bissau-Guinean director Flora Gomes narrate local stories with global developments since they speak of transits, music, women, children, war, neocolonialism, cosmogony, life, death, love, birth, migration, tradition, modernity, collectivity and politics. His films also confront socioeconomic problems related to the ecosystem (deforestation, drought, water). Gomes seems to select themes concatenated with a local and global, social and cultural, reality, but which are in conflict, or imbalanced. When exposed to the public, these themes can foster a revolution in awareness of the particular and collective change of the reality. The titles of Flora Gomes use as setting the ordinary space, the open air: the middle of the bush, in the war, in the city, the neighbourhood, the desert, the tabanka, the street, the beach, in Africa or Europe; with ironic, critical and metaphorical tones of speech, through dialogues without much confrontation between the characters, but that allow a more considerable freedom in the exploration of the discursive texts, which are interpretive and reflective. By presenting authorial speeches, styles and opinions on symbolic, historical, philosophical, cultural or political meanings, not only in his speech, but also in his films, which emphasize the importance of filming on the African continent, to think about its mysteries, virtues and difficulties of the present, past and future, abstaining from irreducible traditionalism and fundamentalism.

\section{2 | THE NARRATIVE ISSUE OF FLORA GOMES [1]}

In this sense, the style of Flora Gomes communicates with delicacy, exposing the local and global situation 
without partisan declarations; avoiding easy methods of interpretation of reality; with ironic dialogues, directing the viewer to reflect and think for himself. Gomes carries the weight of the wisdom of a griot and the need to present in his films his speech on the memory and history of Guinea-Bissau and Africa, against the oblivion of the recent past, which lives the world, in search of a multi-colored, rainbow-colored world, utopian and daring, to go beyond what the minds and bodies still colonized presuppose, proposing we dare to go beyond the expectations created for the young, when death is our only certainty (Nha fala). Like a griot of an "intermediary [memory] that dialogues with the ancestors, which connects the worlds" (Có, 2009:106). Not only the worlds of the living and the dead,but the worlds of the north and the south, of "We" and the "Others", the scholar and the popular; narrating stories that refer to his life, his art, his culture, his country, his history, as he points out himself.

Amílcar Cabral represents a reference, as are all Guineans, the old, the women, and especially the children with their eyes and their smile when they play - that's all that connects me to my country. [...] Guinea-Bissau will inevitably remain my reference: the environment, our language that I love so much the Creole, our dance, our lack of resources. These represent the points of reference that enrich me continuously and allow me to evolve, to grow (Fina, 1995: 46).

And specifically corresponding to the writing of the script, the novel ideas of the films are directly related to the collective memory, the culture, the history of Guinea-Bissau, Africa and the world, demonstrating the capacity and ability of the director in transforming the experiences of his life, his space, his specific and collective memory, in art, an image, in film. The film, whose title "Mortu nega" means, in Bissau-Guinean Creole, is not only "the one denied death, rejected" but also something that is related to the culture, history and orality of Guinea-Bissau.

When a woman gives birth and the child dies in the first, second, third or fourth time; the next surviving child receives the name of Mortu Nega - refused by death ... I used the title, representing those who should die during the fight and did not die, the worthless, those who survived, those which even death has refused (Oliveira; Zenun, 2016: 329).
The critical element of the plot of Udju azul di Yonta is a letter in which a poem appears. The letter was reproduced by Zé from a book, possibly Portuguese/European, where the physical characteristics of a white woman, with blue eyes, are highlighted, as well as climatic factors, like snow, that do not match those of the scenery presented by the film. Besides the problematic that confers to the film its title, the plot is dedicated to discovering who is the admirer of Yonta. In an interview with researcher Frank Ukadik (2002), Flora Gomes adds that there is a concern on how the canonical criteria of what is beautiful and good have been established and instituted. At that moment, these parameters must be questioned, modified, outdated and/or deconstructed, to mark the political, cultural, artistic and aesthetic diversity that the African continent contemplates. Otherwise, the film attempts to describe the dynamics of the colonial and neocolonial system, as well as to problematize its lasting effects on the governmental structure and social dynamics of modern African states.

Po di sangui symbolically and hopefully stages the future of the village and the need for awareness and concern for the future of the environment. Through the final narrative of a child, through drawings of animals/anthropomorphized machines, we are invited to think about the future of the ecosystem. An inspired, ecological-themed fiction film, as Mortu nega, in Bissau-Guinean culture and tradition: "There is an animist root, a cult of nature, and these taboos help preserve the places" (Lusa, 2017) - a local and cultural history of Guinea-Bissau, which goes beyond the territorial borders since the preoccupations with climatic changes are a worldly responsibility.

Already in Nha fala, Flora Gomes produced and staged a story that may well symbolize Africa: the plot of a female character who was, for a long time, prohibited from expressing itself through her voice. Symptomatically, the director names such a character as Vita, "life". In turn, as explained by Gomes, the expression "Nha fala" means "my voice", "my destiny", "my life" and "my way" (Biofilmography - Notes by the director, 2002). The plot of Nha fala focuses on the figure of the woman, although initially, the filmmaker has wanted to develop a story about a boy. However, he was warned to deal with the feminine because in addition to being able to address the right of self-affirmation, he could also consider the issue of freedom of expression. Serge Zeiton, the 
producer of the film, said in an interview that the metaphor of the ban on singing seems considerably stronger when it accosts the woman.

In this sense, it is necessary to ask if the title Nha fala exclusively refers to the acquisition of voice by the Vita character or if it involves the figure of Amílcar Cabral - a voice, a cultural speech that preaches necessary compatibility between tradition and contemporaneity. In the film, the Bissau-Guinean cultural heritage, transmitted orally, still focuses on the story of a woman who cannot sing, reiterating the strength of the voice and the words, while reinforcing its importance and sacralizing its force. A woman who, to satisfy the wishes of her ancestors and promote reconciliation with tradition, realizes: "that to be reborn one must accept death", says the character Vita before her return. Establishing the relationship with the African cosmogony: life-death-life, to satisfy the tradition's desire, which has been broken, she must die, but it will suffer a symbolic death to be reborn stronger and with its bonds with the tradition firmer than never.

In her latest feature film, Republica di Mininus, Flora Gomes develops a unique plot of hope in constructing a better world, especially for children. This is through the fantasy of a nation in which children rule the world and do not grow, since growing up could corrupt them. It can be heard in the introductory voice-over: "It happens today. It is not in Africa but in the whole world. It is the end of the world, which requires a better world to be built, reiterating the drama of child soldiers, the lack of prospects for the future of children and the violence of wars can happen anywhere in the world, not only in Africa".

In the films of Flora Gomes, the signs of displacement and coexistence unfold, by places more fascinating than terrifying to mark the life of the characters and their ensemble. Initially in Guinea-Bissau with the displacement of the characters in their own territory, from the interior to capital, in the Mortu nega; and in the transit of the characters through the streets and districts of Bissau, as in Udju azul di Yonta. In Po di sangui, the movement of the characters takes us on an initial journey from the Amanha Lundju village to desertified landscapes, from Guinea-Bissau to Tunisia and the subsequent return (Guinea-BissauTunisia-Guinea-Bissau, Africa-Africa), in search of better climatic conditions. In the film Nha fala, Vita spends much of the film moving, either because she walks in the streets seeking a place for the statue of Cabral in Green Cape, or because she flees from Yano or the people in the street, or is she travelling (Guinea- Bissau-France-Guinea-Bissau, AfricaEurope). At the end of the film, the group of children led by Railroad march along rural and urban roads in Mozambique.

Music and dance are of fundamental importance in African culture because they represent ways of celebrating which are part of the temporal and spiritual daily reality, which in Africa can be perceived as inseparable from the day-by-day life. It should be noted that music represents part of the social and cultural life of Guinea-Bissau "in all stages of life: birth, initiation, marriage, work, leisure, relationship with God or the world of spirits and death" (Monteiro, 2016). For this reason, music, rhythm, sound, and dance play a central role in the plot of Gomes' films: Sometimes, it emerges as a cultural, traditional, critical and rhythmic leading figure, allowing a multitude of possible analysis. Hence its relevance in the films, in which it gains a vaster force, which soundtrack comprises all the sounds present in the film, including the lack of sound: silence. This, for Gomes, is part of the soundtrack; remaining a sound choice for his films, and is, until today, a source of inspiration.

Consequently, the soundtrack is a mark, and great concern of the filmmaker. This, as well as other aesthetic aspects, has a huge effect on the viewer, being able to provoke emotions. The music of the movie Mortu nega is signed by Sidonio Pais Quaresma and Djanuno Dabo [2]; the musical work of Udju azul di Yonta was recorded by Adriano Atchutchi and other members of the Bissau-Guinean group Super Mama Djombo [3]; the music of Po di sangui is signed by Pablo Cueco [4]; the track of the musical Nha fala is signed by Cameroonian musician and saxophonist Manu Dibango [5]. In his latest feature, Republica di mininus, in which "music represents a character [and] serves to illustrate the film" (Nunes, 2013), the soundtrack is by Senegalese musician Youssou N'Dour [6].

The music allows adaptability to the film's nature because it is an adjustable component of the film: i.e. it can be one of the elements included after the shooting. In this manner, the song in the film coexists with noises, voices, and silence. Silence, as already mentioned, Gomes's trademark, is very expressive 
and gives the viewer an emotional charge of commotion: "one of the most dramatic and disturbing elements in a film" (Bahiana, 2012: 117). In addition, musicality provides a subversive role that is also used to counter recurrent stereotypes and negative anthropological interpretations. For this reason, one can also "starting with music, to know African realities that have been so silenced; [music] presents itself as fundamental for its revealing purpose "(Leal-Riesco, 2012: 109).

Perhaps for this reason, at the beginning of the 21st century, Flora Gomes ventures into the musical, a classic Hollywood genre. For Beatriz Leal-Riesco, the musicals of the African filmmakers Flora Gomes, Joseph Gaï Ramaka and Mark Dornford-May play a key role in understanding the meaning of the process of direction and "Their films are at once critical and artistically significant in their experimental nature with respect to form as much as to content - and they exemplify the impossibility of reducing the role of music to a set of randomly applicable generalities"(Leal-Riesco, 2011). In Nha fala, there are sounds, whispers, voices, words, lyrics, silences, songs, dances, choreographies, rhythms, melodies elements that converge to tell Vita's life in the musical. So, the main character spends half the film without singing, because of the curse that forbade the women of his family to sing. In part because of this, Vita is described by her boyfriend as unhappy, because she does not sing, although in some moments Vita responds roughly to the immediate questions through the lyrics of the songs, as well as to them, with the various interpellations.

In Gomes' films, the Bissau-Guinean and African oral traditions are very present, not only in the representation of rituals or thematic elements and idiosyncratic questions of his place of birth, but especially for showing on the screen an aesthetic narrative inspired by oral tradition, to narrate the stories collectively, avoiding the historical confrontation in the narratives - underlining perspectives that do not have the purpose of idolatry, savagery, and primitivism idolized by anthropologists and historians, but highlight the local and continental humanism of culture. In view of this, what stands out in Flora Gomes films are the long takes with natural sounds, especially in the film Po di sangui - a look at Guinea-Bissau, which puts the beauty of the characters and traditions in the scenes, sequences, and frames. This representation of a possible "oral tradition, fictional narrative" is clearly evident in this film through the staging of a particular community that fights against the effects of climate change. The story Amanha lundju is narrated collectively, daily. Initially by the tabanka women, notably Antônia, early in the movie, narrating the episode of the twins, the character also stands out as a counselor/great woman. As the film develops the story is also narrated by Calacalado; and in the end by the child, daughter of Hami, but who also recognizes the uncle as father, creating a complicity with the spectator in the construction and unfolding of the story.

It is like an association of elements and institutions, of a particular vision and presence in the world, where everyone participates and occupies its share of responsibility, demonstrating not only the bond between the spiritual and material worlds, but also the various practices involving the national economy and politics in international relations. This view of the African world is based on the principle of a connection between the dead, the living and the unborn. From this angle, the African realities portrayed in Gomes' films must equally be concerned with reproducing this worldview.

Flora Gomes, in addition to signing the screenplay for his films, is a director who produced a method, a technique, to prepare non-actors, non-professional actors and professional actors for staging in front of the camera [8]. Through his method, the director supports the actors to escape the stereotype and directs them into immersion into the world of the characters, allowing the interpretation to be more natural and spontaneous, providing, along with the actress or the actor, the idea of a character of "flesh and blood": "Realist interpretation of an actor is embodied not by his portrayal of the copy of the results of feelings, but by his ability to produce these feelings: arise, develop, transform into other feelings - live before the viewer" (Eisenstein, 2002: 21 "italics in the original").

In this sense, Gomes performs an immersion work with actresses and actors (an activity typically related to the casting figure, a professional who usually works with the actors in the essays, to build characters or lines of action). Flora Gomes has to deal with the difficulty of working with non-professional actors and many extras, especially with regard to mise en scène. Additionally, there is still the obstacle of working with people who do not have the same culture, the same 
time to rehearse, the same educational instruction, the similar socioeconomic levels. As director of actors, Gomes reveals himself to be a man with intuition, sensitivity, patience; a particularly considerate subject to know how to manage and deal with the various groups of people who embody his films.

In addition to the formation of the actors, Flora Gomes' 'school of actors preparation promotes the creation of a network formed among all participants before, during and after the film, reflecting this instruction in the personal and collective transformation of those involved. It is a project of social and cultural formation, according to lapatia Silva [7], an actress who performed the character Awa in the film Po di sangui. Silva points out that Gomes prepared the actors of the film over more than a year, in the sense of cultural, literary and artistic preparation, constantly encouraging the potential of future actors and actresses. It should be mentioned that in the context of such preparation, young people from various social classes were gathered together, and some of these attended meetings, sometimes without breakfast. Faced with this reality, the filmmaker invited those who were more likely to bring food so that everyone could make the meal together. This is how the director promoted socioeconomic and cultural interaction among the participants, as well as stimulating the formation of a collective and community awareness of helping each other.

In his school of actor preparation, Flora Gomes wants to teach actresses and actors (usually nonprofessional actors) to act in front of the camera, which is in line with the Stanislavski method (2016), when it emphasizes the importance of the original creation not as a mere imitation or repetition of what the director wishes. In this sense, Flora works not only in the understanding of staging, but also in the understanding of her culture, in the construction of collective work, through readings of artistic texts, in the visualization of films, in the interpretation of diverse authoral texts (intellectual, cultural, spiritual, physical and emotional). In this way, the technique is learned through training, to express in and with the body, the learning, the interpretation, the staging of the profession, given that the presence of the filmmaker can influence, especially during the rehearsals, the quality of the performance.
This results in the great importance of the external environment in the interpretation, which promotes the sense of realism in the actors. The actors experience the situation on the stage, adjust to the environment, live the character, give life: the actor must be carried away completely. "He then lives the role, independently of his own will, without noticing how he feels, without recognizing what he is doing, and everything goes on his own, subconsciously and intuitively" (Stanislavski, 2016: 42). "We must live it by experiencing similar feelings every time we repeat the process of creating it" (Stanislavski, 2016: 43). As a result, the concern of Flora Gomes with the scenic construction, the availability of bodies in space for dramatic purposes, and the precise organization of compositions and movements within the frameworks, emphasizing the visual poetry of the director, which make the receptors reflect on the representations, spaces, movements of the camera: "The object of the look and the intelligence that constructs the mise en scène is the corporal presence of the actors in a scene, as well as the feeling that the narrative reveals - it is the world, or rather, the aspects of the world that prove themselves capable of acting immediately on our sensibilities" (Oliveira Jr, 2013: 62).

If cinema is the art of vision, space is its fundamental element, which implies thinking and exploring the visual perception of the spectator, but it especially implies reflecting on who organizes such space, that is, the creator: the set designer, the filmmaker, the author (Rohmer, 1948). "In fact, cinema is the first art in which the domination of space could be fully realized" (Martin, 2003: 196). Unlike other arts (dance, theater, sculpture) that are performed in space, cinema is the art of space. This means cinema can faithfully portray the real and material environment, creating a definitely different location. "The film space is a living space, figurative, threedimensional, endowed with temporality as real space, and that the camera experiments and explores; at the same time, the filmic space is an aesthetic reality [...], made dense through describing and assembly "(Martin, 2003: 209-210). The space in the cinema have two perspectives: 1 ) the reproduction of the real (natural) and its transformation happens through the movement of the camera; and 2) the space created (artificial), fragmented and synthetic, but which can also be noticed by the spectator as real.

The settings, be they interior or exterior, can be real that is, pre-exist to the shooting of the film — or built 
in the studio - inside a studio or in its outdoor facilities (Martin, 2003). These two practice sets, sometimes opposite to each other, are used in contemporary cinematography - Hollywood cinema, for example, in science fiction films, favors studio or virtual/digital settings. Flora Gomes has repeatedly opted for sequences filmed in a natural environment: urban spaces (Bissau, Green Cape, Paris, and Mozambique); roads of Bubaque; the fort of Cacheú; the desert of Tunisia. The natural landscapes of the places where the director circulates become scenarios of his films. In his work, even when it is necessary to construct scenarios, Gomes chooses to perform in a natural environment; like the tabanka in the film Po di sangui, or in Mortu nega, when he looks to demonstrate historical similarity in the construction of the natural setting to stage the space of the struggle for independence against Portuguese colonialism.

At the moment when he is specifically asked how he idealizes his scenarios, Gomes is categorical: "They are natural sceneries. I like everything that is natural. I've been looking to choose the Po di sangui scenery. I almost walked all of Guinea to find the setting for Mortu nega. All those décors with the military. It was not easy! "(Gomes, 2018). These two cinematographic spaces highlighted by Gomes are important because through them the director also becomes a set designer. He signs the scenario of Mortu nega with the collaboration of Manuel Rambault Barcellos and the one of Po di sangui with Anita Fernandez since the paper of the step-people becomes important and of prominence, because "the mise en scène, in the last analysis, would be the power to copy natural beauty. If, on the one hand, cinema does not manufacture this beauty, on the other, it raises it" (Oliveira Jr, 2013: 49). The scenes of the other films are signed by Miguel Mendes (Udju azul di Yonta), Véroniuqe Sacrez (Nha fala) and Tim Panner (Republica di mininus). Nevertheless, it is important to emphasize that Flora Gomes participates directly in the choice of the spaces of its films.

Colors and illumination are a concern, ranging from the pre-production to the post-production of Flora Gomes, especially with regard to the light on the black bodies and the color of the ethnic-racial constitution of the representation of the African continent and the world. As a result, the filmmaker turns the cinema into a fighting weapon, using it to portray black actors and actresses, natural scenes and diverse realities. Therefore, with his cinema, the director wants to deconstruct the image of an exclusively black continent - painted with a unique color, related, throughout history, with "ugly", diseases and epidemics - to relate it to diversity of colors and the realities that the continent has, thus seeking "[...] to find a space, without wanting to kill the other one that is there, but how can I fit in that space that is there, empty, that is, possibly even with intentions and that is reserved for the other, the person most similar to him"(Gomes, 2015); painting "Africa different from the painting which they had painted" (Gomes, 2016). As a black and African filmmaker, Gomes considers "being black" as natural and free, so, with such characteristics, he declares himself "a black free man ", because I want to fly very high, in free space. And I want to illuminate my space to make the film with the black light "(Gomes, 2015).

The lighting of black bodies in the films of Flora Gomes contrasts with the image of the first ethnographic portraits of the colonial period, which showed black men as animals, goods without history; images that idealized Africa as a jungle, representing black men and women "as objects within the history of photography" (Amkpa, 2012: 10), or as " coal that was painted in colonial photography or bathed in milk" (Gomes, 2016). Gomes's work diverts from the ethnographic cinema that tries to reproduce or document African reality as fixed, immutable and primitive, leaving aside also the modernity of the continent, urban spaces, cities and city landscapes. "However, this began to change when African photographers [and filmmakers] began to use their art to resist the colonial anthropological frameworks of subalternity" (Amkpa, 2012: 10). Among these, the films of Flora stand out, because they display on the screen beautiful sets, and frames, of black actors and actresses.

The care and responsibility with the lighting of the black body in the films of Flora Gomes are evident from the beginning of its filmography, including in the relationships built with the director of photography: "I usually, in terms of light, I tell the director of photography what I want, even it being of its total responsibility; and in the case of my collaborators, it is complicity "(Gomes, 2018). He confirms that, since his first film, he was "lucky to work with many good directors of photography" (Gomes, 2018). His collaborators, in the composition of photography, 
were: Dominique Gentil (Mortu nega and Udju azul di Yonta), Vincenzo Marano (Po di sangui), Edgar Moura (Nha fala) and João Ribeiro (Republica di mininus). According to Antonio Costa (2003) the role of the director of photography is to prepare and coordinate the lighting of the scenes to be filmed, with light that can be made by means of reflectors and reflecting surfaces, which can be oriented in various ways, low, "with cut", etc.) and distributed in many other forms (direct, diffuse ...). So the director of photography has, together with the director, the burden of creating the visual expression of the film.

Even with the challenges and difficulties of lighting the black body (alone or with other skin tones), Flora Gomes is concerned with balancing the colors of two extremely different skin tones to produce more abstract and conceptual meanings, in this manner evoking symbolic implications for the scheme color, lighting, scenery. An example of what is argued here can be seen in the sequence shot in Paris, centered on the characters Vita and Pierre, in the film Nha fala: Vita and Pierre are naked in a room; they kiss. The scene is short, but clearly demonstrates the color differences between the black and white skins, including using close-ups on parts of bodies (trunks, faces, arms, and hands tangled and intertwined). The scene for Flora Gomes is a visual metaphor for the construction of the various skin tones in the world, of métissage, even related to the dialogue of Pierre's mother, when she suggests she should get used to the possibility of having grandchildren darker than him.

The opening, promotion, creation and manufacture of new products that reproduce the diversity of colors and skin tones of contemporary society - among other cases: band-aids, mannequins, dolls, nylon stockings, makeup, crayons, movies, and television screens - have come about as a result of multiple historical factors, including (though not always) demands of the civil rights movement for more products appropriate for the various shades of skin. Lorna Roth (2009) points out that other factors also imply responses from regional, national and global industries to consumer demands for the transracial integration of ethnically and racially coded products: negative consumer reactions to the given product division; line available to the "white" population separate from those available to the "ethnic or racialized" market; changes in the target audience that reached the industry, showing the silencing of this public towards companies and manufacturers, which were (and still are) ignored by technicians and researchers.

\section{3 | CONCLUSIONS}

At present, the image of blacksand Africans is still very stereotyped. However, there is already advance in the debate around technical photography and conceptually, followed by the increase of the representation of the blacks in the screens. And all this with the aesthetics of focused representation for black or African descent people, carving the black skin on the screen, not glossing it, supports the need to decolonize the images, the techniques, machines, minds, and bodies still colonized and attached to ethnocentric models and white patterns and models.

In this way, the authorship of Flora Gomes refers especially to local-based universalism, which presents aspects of the black aesthetic, with concerns about the preparation of actors, scenery and lighting of the body; with reflections about African cinemas, through cinematographic language, making films that please African, American, European and Asian audiences with great artistic, academic and commercial value; proposing, with the camera in African and African hands, to create new images of the world, of the Africans, of Africa; looking to stimulate debate, curiosity, dialogue, representativeness over images, films and the arts. Gomes looks for this course with original films that can also meet the demand of an audience increasingly conditioned by the uniformity of the cinema proposed by the Hollywood model. Yet, the resistance of experimenters of new forms of cinematographic making shall prevail - pioneers of new paths and new aesthetics like those of Flora Gomes, so that the future of cinema is guaranteed.

\section{ENDNOTES}

[1] For more theoretical information see Oliveira (2018).

[2] Sidonio Pais Quaresma is an author, composer, singer, and guitar player from Guinea-Bissau. He sang in the group Sabá Miniambá with some friends.

[3] Adriano Gomes Ferreira Atchutchi is the leader of Super Mama Djombo. The group was created in the 1960s under the name of Mama Djombo, which is the name of a very powerful Iran (spirit) in Guinea-Bissau, invoked as protection during the struggle for 
independence. The musical ensemble is directly related to Bissau-Guinean musical culture and history, since their lyrics, at the time of the struggle, encouraged the liberation movement, including songs that tell the story of confrontations and Amílcar Cabral.

[4] Pablo Cueco is a French zarbista and composer. "Zarpista" is related to tombak or zarb, which is a percussion instrument of Iran.

[5] Emmanuel N'Djoké Dibango was born in Douala, Cameroon, in 1933. He is a saxophonist of rhythms such as jazz and afrobeat. Afrobeat represents a combination of music yorubá, jazz, highlife, funk and rhythms fused with African percussion and vocal styles, popularized in Africa in the 1970s.

[6] Youssou N'Dour was born in Dakar. He is a Senegalese composer, performer, musician, and politician. He has worked with several international artists such as Peter Gabriel, Paul Simon, and Manu Dibango. He has received international recognition for his song Seven Seconds,recorded with the singer Neneh Cherry. The composition La Cour des Grands was the anthem of the World Cup (1998). He is a goodwill ambassador to the United Nations and UNICEF.

[7] Actress Fatou N 'Diaye, and actors Ângelo Torres and Jean-Christophe Dollé are professional actors who, at the time of Nha Fala's performance, were at the beginning of their professional career. Meanwhile, Ângelo Torres, with whom she had shared a presentation and discussion of the film, in Lisbon, says that participation in the film represents a very important event in his curriculum. Already in the film Republica di meninus, there is the special participation of the American actor Danny Glover.

[8] At the time of the preparation of this film, lapatia Silva was 16 years old. She currently lives in France but maintains remarkably strong ties with GuineaBissau, a country she visits at least twice a year. Silva works with marketing and beauty products design in France. The interviews that serve as material for the present thesis (sometimes conversations) happened in Bissau, during the realization of field research (2016).

\section{REFERENCES}

Amkpa, Awam (org) (2012). Catálogo Africa see you see me!: influências africanas na fotografia contemporânea. Portugal: Sextante Editora.

Bahiana, Ana Maria (2012). Como ver um filme. Rio de Janeiro: Nova Fronteira.

Có, João Paulo Pinto (2009). Nha fala: entre memórias, esquecimentos, ancestralidade, oralidade e identidade nacional guineenses numa África póscolonial. In: Griots: culturas africanas: linguagem, memória, imaginário. Natal: Lucgraf. p. 102-113.

Costa, Antonio (2003). Compreender o cinema. Trad. Nelson Moulin Louzada. 3.ed. São Paulo: Globo.

Eisenstein, Sergei (2002). O sentido do filme. trad. Teresa Ottoni. Rio de Janeiro: Jorge Zahar Ed.

Fina, Cristina (1995). Entrevista com Flora Gomes. In: Cinemas de África - Catálogo. Lisboa: Cinemateca Portuguesa; Culturgest, 1995, p.44-49.

Gomes, Flora (dir.) (1988). Mortu nega (Morte negada). [Filme].

Gomes, Flora (dir.); Sousa, Paulo de (prod.) (1992). Udju azul di Yonta (Olhos azuis de Yonta). [Filme].

Gomes, Flora (dir.); Gallepe, Jean-Pierre (prod.) (1996). Po di sangui (Pau de sangue). [Filme].

Gomes, Flora (dir.); Teles, Luís Galvão; Thiltges, Jani \& Zeitoun, Serge (prod.) (2002). Nha fala (Minha fala). [Filme].

Gomes, Flora (dir.); Artemare, François (prod.); Mayer, Maria João (prod.) (2012). Republica di mininus (República de meninos). [Filme].

Gomes, Flora (2015). Entrevista concedida à Jusciele Oliveira. Lisboa, maio 2015.

Gomes, Flora (2016). Entrevista concedida à Jusciele Oliveira. Lisboa, maio 2016.

Gomes, Flora (2018). Entrevista concedida à Jusciele Oliveira. Lisboa, maio 2018.

Leal-riesco, Beatriz (2011). The role of music in African cinema. In. Afroscreen. 16 May 2011. http://www.buala.org/en/afroscreen/the-role-ofmusic-in-african-cinema. 
Leal-riesco, Beatriz (2012). A caminho de um amadurecimento na utilização da música no cinema africano: Sembene, Sissako e Sené Absa. In:. Filmes da África e da diáspora: objetos de discursos. Salvador: EDUFBa, p. 101-128.

Lusa (2017). Aldeias da Guiné acreditam nos espíritos da floresta e isso protege o ambiente. Publicado em 11 de fevereiro de 2017. .https://www.rtp.pt/noticias/cultura/aldeias-da-guineacreditam-nos-espiritos-da-floresta-e-isso-protegeo-ambiente_n982298.

Martin, Marcel (2003). A linguagem cinematográfica. Trad. Paulo Neves. São Paulo: Brasiliense.

Monteiro, Vladimir (2016). A música na Guiné-Bissau (em toda a sua diversidade). http://vozdaguine.com/musica-guine-bissau/.

Nunes, Roni (2013). Entrevista a Flora Gomes, o realizador de «República di Mininus». Publicada em 16 de maio de 2013. http://www.c7nema.net/entrevista/item/38976entrevista-a-flora-gomes,-o-realizador-de-republicadi-mininus-estreia-maio.html.

Oliveira, Jusciele; Zenun, Maíra (2016). A poesia universal no cinema de um homem africano: entrevista com Flora Gomes. In. Cerrados - Revista do programa de pós-graduação em literatura. n. 41, p.320-329.
Oliveira, Jusciele (2018). "Precisamos vestimo-nos com a luz negra": uma análise autoral nos cinemas africanos - o caso Flora Gomes. TESE. Portugal: Centro de Investigação em Artes e Comunicação, Universidade do Algarve CIAC-UALG.

Oliveira Jr, Luiz Carlos (2013). A mise em scène no cinema: do clássico ao cinema de fluxo. Campinas/SP: Papirus.

Rohmer, Eric [Jean-Marie Maurice Schérer] (1948). Le cinéma, art de l'espace. In. La Revue du Cinéma, n.14, juin 1948, p. 80-82.

Roth, Lorna (2009). Looking at Shirley, the Ultimate Norm: Colour Balance, Image Technologies, and Cognitive Equity. In. Canadian Journal of Communication, v 34, p. 111-136.

Silva, lapatia (2016). Entrevista concedida à Jusciele Oliveira. Bissau, março 2016.

Stanislavski, Constantin (2016). A preparação do ator. Trad. Pontes de Paula Lima. 34.ed. Rio de Janeiro: Civilização Brasileira.

Ukadike, Nwachukwu Frank (2002). Questioning african cinema: conversations with filmmakers. Minneapolis: University of Minnesota Press. 
